微細石灰化像の基礎と臨床(5)

\title{
愛知県がんセンター乳腺外科におけるマンモグラフィで 微細石灰化像のみを呈する非触知乳癌の診療システム
}

水谷 三浩 遠山竜也 亀井桂太郎 岩田 広治

愛知県がんセンター乳腺外科

\begin{abstract}
当科では, 最新の技術を駆使した精緻かつ低侵襲な術前診断から適切な縮小手術に到る 診療システムの構築を目指している。そこで今回，微細石灰化像のみを呈する初治療の非 触知乳癌 46 病変を対象とし, 当科の診療システムを検証した。その結果, 超音波で異常所 見 (充実性低エコー像)を認めたものが $80 \%$ と大半を占め, 超音波ガイド下穿刺吸引細胞診 で確定した症例が54\%であったことから, 微細石灰化像のみを呈する非触知乳癌の診療に 扔いても高分解能装置を用いた超音波検查の有効性が確認された。また低侵襲の画像ガイ ド下のインターベンション(細胞診, マンモトーム)により $91 \%$ 確定診断されたことか ら，侵襲の大きな切開生検などの組織診は最終手段に位置づけるべきと考えられた。さら に超音波による微細石灰化の認識の可否において, マンモグラフィ所見での石灰化の淡さ や拡がりおよび癌の浸潤の有無が決定的な因子ではないと判断された。微細石灰化のみを 呈する非触知乳癌は超音波で確認できたとしても, 同計測上 $1 \mathrm{~cm}$ 以下の微小なものが多 く，その診断は容易とはいい難い。しかし縮小手術のもたらす QOL 向上や良好な予後か ら, 同乳癌を診断する意義は大変大きい。今後, 高精度のマンモグラフィ検診により非触 知の微細石灰化を呈する数多くの症例の発見が尒想される。精緻かつ低侵襲の画像診断・ インターベンションを実践できうる診療システムの構築が求められている。
\end{abstract}

Key words : 微細石灰化, 非触知病変, マンモグラフィ, 高分解能超音波, 診療システム

\section{はじめに}

非触知乳癌を含む早期乳癌の診断において，マ ンモグラフィの微細石灰化像は非常に重要な所見 である。しかるに微細石灰化像の評価において， 以下の事項を念頭に置かねばならない。

すなわち,

1)微細石灰化は良性疾患にも伴われることがあ

り，悪性所見と断定できない，

2)確定診断のために組織診まで要する症例が多

別冊請求先： $\mathbf{T} 464-0021$ 名古屋市千種区鹿子殿1-1 愛知県がんセンター乳腺外科 水谷三浩 E-mail address :mmizutan@aichi-cc.jp
い,

3)症例毎に診断手順の個別化，適正化をはかる 必要がある,

等に留意して慎重に評価すべきである。したがっ て当科では微細石灰化を呈する症例に対し，最新 の技術を駆使した精緻かつ低侵襲な術前診断から 適切な縮小手術に到る診療を実践している。

実際の診断手順 (図 1)を述べると，ルーチン検 查後, まず高分解能超音波装置使用下に穿刺吸引 細胞診 (USABC)を施行する。症例によってステ レオガイドマンモトームも併用するが, 細胞診で 大半の確定診断は可能である。乳頭状病変などで インターベンションテクニックによる確定診断の 困難な症例では，前もって MRI 等により病変の 


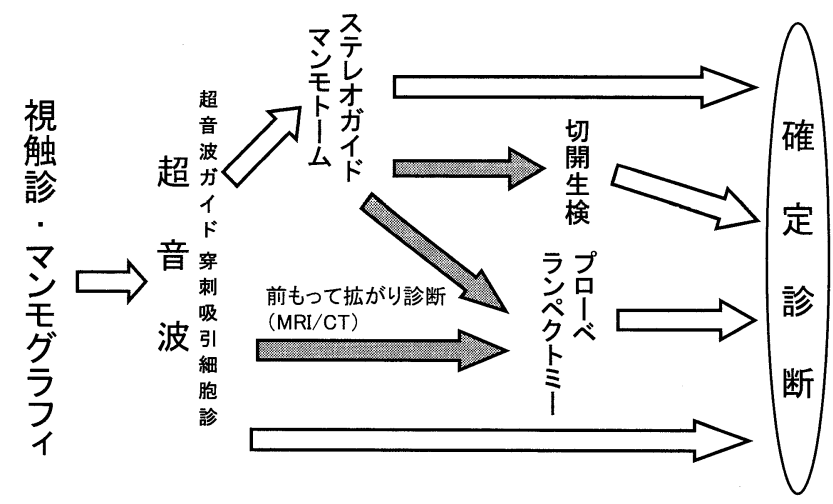

図 1. 微細石灰化を呈する非触知病変の診断手順

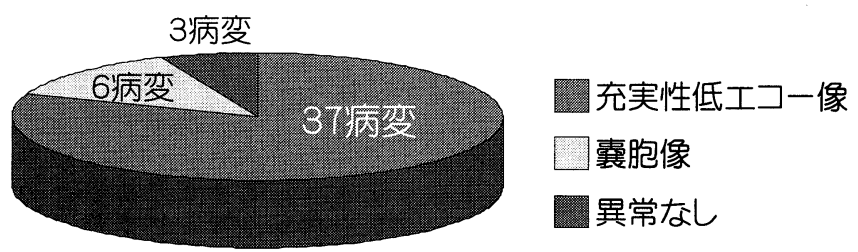

図 2. 超音波所見

拡がりを充分評価したうえで組織診を施行する， というものである。

今回われわれは微細石灰化を呈する症例に対す る当科の診療システムを検証し, 報告する。

\section{1. 対象と方法}

1999年 4 月～2002年 9 月の期間の他院生検例を 除く当科の初治療の微細石灰化のみを呈する非触 知乳癌 46 病変を対象とし, 臨床 (画像診断, 手術 など) と病理の両面から検討した。46病変の微細 石灰化の形状別の内訳はPunctate 4 病変, Amorphous 18病変, Pleomorphic 21病変, Linear 3 病変。石灰化の分布別にみると, Clustered 22 病変, Segmental 20 病変, Regional 2 病変,

Scattered 2 病変であった。

46病変の病理組織型別の内訳は, 非浸潤性乳管 癌34病変, 乳頭腺管癌11病変(微小浸潤癌 7 病 変), 粘液癌 1 病変であった。

マンモグラフィ撮影装置は GEYMS 社セノグラ フ600T, 超音波装置は GEYMS 社 LOGIQ700MR を使用した。

\section{2. 結 果}

\section{1)超音波所見}

非触知微細石灰化乳癌46病変の超音波所見 (図 2)は，腫瘤像もしくは不整低エコー域などの充実 性低エコー像を呈したもの 37 病変 $80 \%$, 震胞像 6 病変 $13 \%$, 異常を認めなかったものが 3 病変であ った。

\section{2)確定診断}

非触知微細石灰化乳癌 46 病変のうち, USABC で 25 病変 $54 \%$ ，ステレオガイドマンモトームで 17 病変37\%が確定診断（図 3) された。

つぎにUSABCで診断の確定した症例群と非確 定群とを, 微細石灰化の形状と分布および病理組 織型別に検討してみた。

\section{3) 微細石灰化の形状}

USABC で診断の確定した症例の占める割合を 微細石灰化の形状別にみる(図 4) と Punctate 4 病 


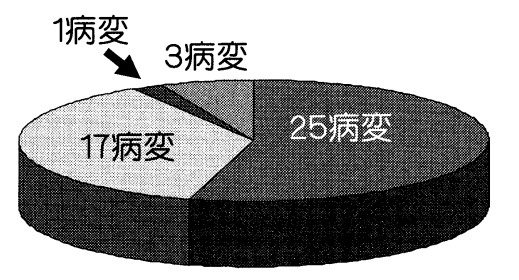

ind UABC

匈ステレオガイドマンモトーム

超音波ガイド

プローベランペクトミー

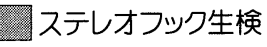

図 3. 確定診断

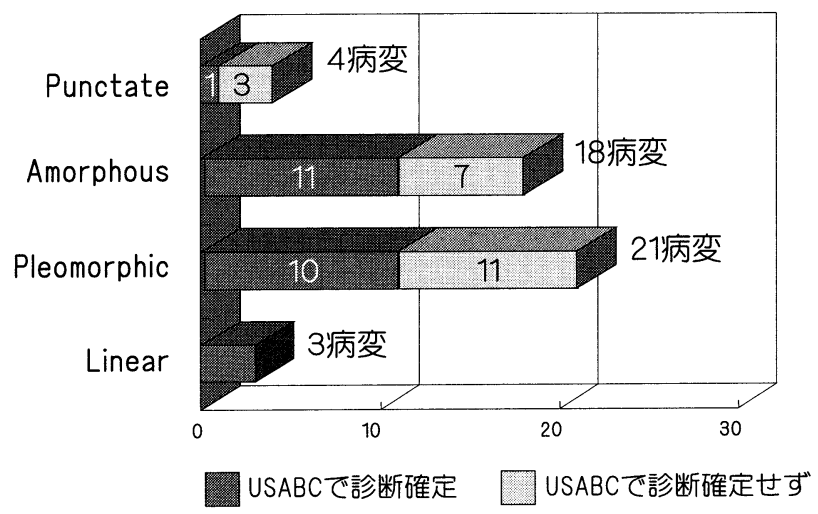

図 4. 微細石灰化の形状

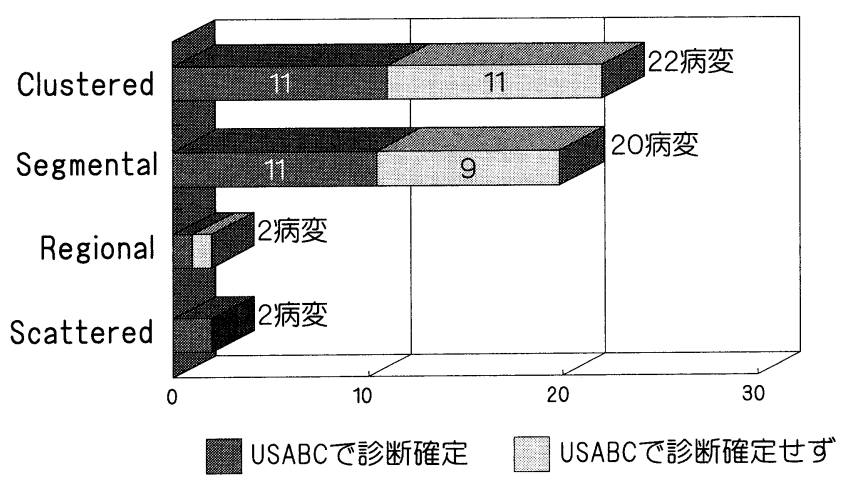

図 5. 微細石灰化の分布

変中 1 病変 $25 \%$, Amorphous 18病変中 11 病変 $61 \%$, Pleomorphic 21 病変中 10 病変 $48 \%$, Linear は 3 病 変全例100\%であった。

\section{4)微細石灰化の分布}

同様に微細石灰化の分布別にみる(図5)と Clustered 22 病変中 11 病変 $50 \%$, Segmental 20 病変
中 11 病変 $55 \%$, Regional 2 病変中 1 病変 $50 \%$, Scattered 2 病変は全例100\%であった。

\section{5)病理組織型}

USABC で診断の確定した症例の占める割合を 病理組織型別にみた内訳(図 6)は, 非浸潤性乳管 癌 34 病変中 18 病変 $53 \%$, 乳頭腺管癌 11 病変中 6 病 


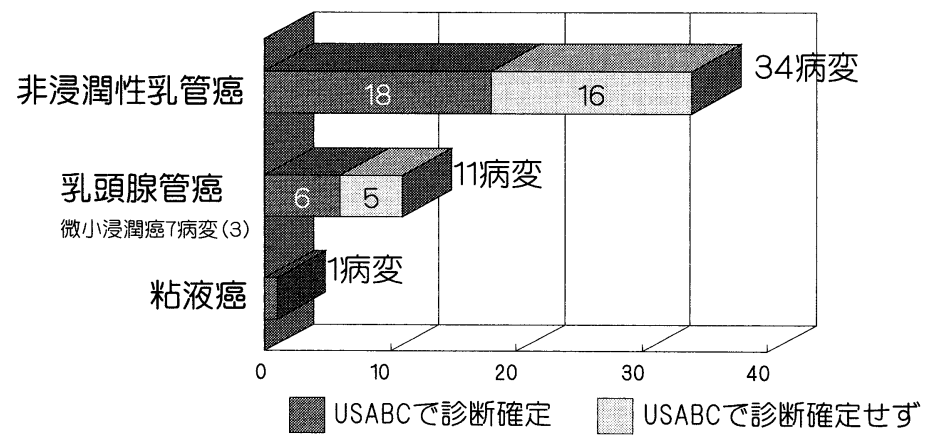

図 6. 病理組織型

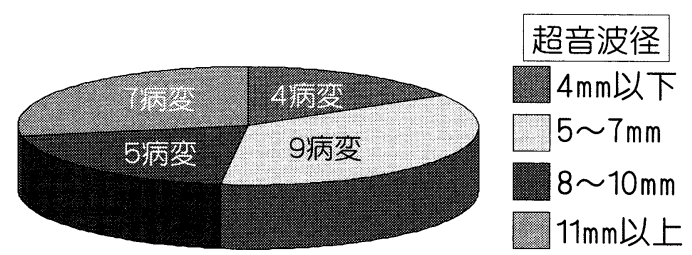

図 7. 超音波測定上の病変の大きさ (USABC で診断が確定した微細石灰化25病変)

変55\%(このうち微小浸潤癌 7 病変のうち 3 病 変), 粘液癌 1 病変 $100 \%$ であた。

\section{6)超音波による病変の計測}

USABC で診断が確定した微細石灰化25病変に おいて，超音波で充実性低エコー部を測定した最 大径は $5 \mathrm{~mm}$ 未満 4 病変, $5 \sim 7 \mathrm{~mm} 9$ 病変, 8 $\sim 10 \mathrm{~mm} 5$ 病変, $11 \mathrm{~mm}$ 以上 7 病変といった内訳 (図 7)であった。

\section{7)術 式}

当科の術式選択の基本方針として，「MRI など により詳細に拡がりを評価した後，病変の遺残な く整容可能と判断されれば温存術の適応」と考え ている。この方針にそって非触知微細石灰化乳癌 46 病変の根治術を施行し，温存術は21病変 $46 \%$ に, 乳房全切除は残る 25 病変 $54 \%$ (図 8) に施行さ れた。

\section{8)リンパ節郭清}

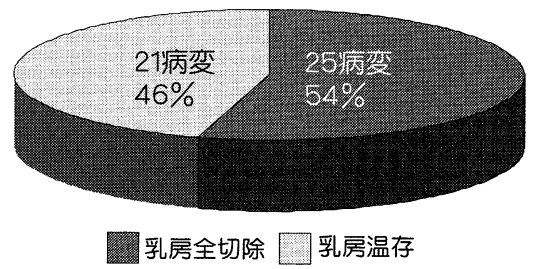

図 8. 術式

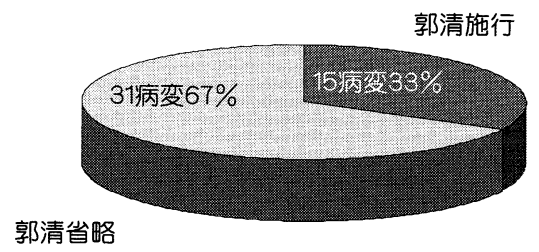

図 9.リンパ節郭清

当科のリンパ節郭清を適応する現行の基本方針 は，「諸検査の総合判断にて非浸潤癌と判断すれ ば郭清省略，浸潤が予想されても浸潤径 $2 \mathrm{~cm}$ 程 度ならばセンチネルリンパ節生検を積極的に施行 し，陰性例は郭清省略」としている。非触知微細 石灰化乳癌46病変のリンパ節郭清の有無の割合 （図 9）は郭清あり15病変33\%で，郭清施行例のう ちリンパ節転移陽性と判明したのは 1 病変であっ た。なお郭清省略例 31 病変 $67 \%$ のちセンチネル リンパ節生検施行は15病変である。

\section{3. 考 察}

当科では診療方針の原則として， 
1)必ず良悪性の確定診断をつける,

2)切開生検は最終手段とし, 侵襲の小さい検査 を先行させる，

3)切開生検などの組織診の前に, 常に拡がり診 断を行う,

4) 画像相互ならびに画像とインターベンション の所見の整合性を鑑み，総合的に診断する，

5) 縮小手術の可能性を念頭に置き, oversurgery を可及的に避ける，

等の事項を重要視している。この方針に基づいて 微細石灰化を呈する非触知病変の診断手順につき 図 1 のごとく構成した。かつて非触知石灰化乳癌 の超音波による評価・診断は難しく, 乳房超音波 検査の弱点とされた経緯があった。その窮状を打 破すべく, 高分解能フルデジタル装置は登場し た。同装置の開発は高周波化・広帯域化の進んだ 探触子による解像度の著明な改善をもたらし, そ の成果として乳房超音波検查の診断精度が飛躍的 に向上したのである。

今回のデータは無論のこと, 前述した現在の当 科の診療方針ならびに診断システムも高分解能超 音波装置の存在なくしてはありえなかった。その 成果は図 2 に如実に示されている。非触知微細石 灰化乳癌の超音波で異常所見(充実性低エコー像) を呈したものが80\%と大多数であった。加えて USABCで診断の確定した症例が54\%(図 3) あ り, 微細石灰化像のみを呈する非触知乳癌の診療 においても高分解能超音波装置を用いた乳房超音 波検査は診断手順として最初の精査と位置づけら れよう。またUSABC とステレオガイドマンモト ームで確定診断されたものを合わせると $91 \%$ とな り，侵襲の大きな組織診は最後の手段にすべきと 考えられる。とはいえ非触知微細石灰化乳癌のす べてが超音波で診断されるわけではない。

どのような非触知微細石灰化乳癌が超音波で認 識されるのだろうか。ここでUSABC で診断の確 定した症例, 換言すれば間違いなく超音波で病変 を描出しえた乳癌の占める割合をその微細石灰化 の形状と分布および病理組織型別に比較検討して みた。その結果，まず形状(図 4 )では, Amorphous
は淡く不明瞭な石灰化の意であるにも関わらず, Amorphous (61\%)が Pleomorphic (48\%)を上回っ た。ついで分布別(図 5 )にみると, Clustered (50\%), Segmental (55\%), Regional (50\%)の三 者間に大差はなかった。病理組織型別(図6 )で は, 非浸潤癌 $(53 \%)$ よりも微小浸潤癌 $(43 \%)$ が低 かった。したがってマンモグラフィでの石灰化の 淡さ (=大きさ, 濃度)や拡がり, 癌の間質浸潤の 有無が決定的な因子ではないと判断される。

さてUSABC で診断が確定した乳癌例において 充実性低エコー部を測定した結果 (図 7 ), 超音波 径 $1 \mathrm{~cm}$ 以下のものが多く $(72 \%)$, その超音波診 断は容易とはいいがたい。しかしながら温存術 (図 8 )やリンパ節郭清省略(図 9 ) といった縮小手術 のもたらす QOL 向上や良好な予後への期待か ら, 微細石灰化像のみを呈する非触知乳癌を診断 する意義は大変大きい。今後, 高精度のマンモグ ラフィ検診により非触知の微細石灰化を呈する数 多くの症例の発見が予想される。精緻かつ低侵襲 の画像診断・インターベンションを実践できうる 診療システムの構築が求められている。

\section{4. 症例提示}

良悪性を含め非触知病変の 3 例を供覧する。 [症例 $1 ： 39$ 歳女性] 超音波で微細石灰化と一致 する echogenic spotを認めたが, USABCで良性 と確定するには不安があり, ステレオガイドマン モトームまで施行し, 線維腺腫と最終診断。

[症例 $2 ： 52$ 歳女性] USABC で悪性を疑われ た。MRIにて限局性病変と確認したうえで, 診 断と治療を兼ねて超音波ガイド下プローベランペ クトミー施行。病理診断で DCIS, 断端陰性。

[症例 $3: 65$ 歳女性] 超音波所見で, 内部に echogenic spotを有する不整形腫瘤像を認め, USABC で悪性と診断。

\section{おわりに}

今回微細石灰化を呈する症例に対する当科の診 療システムを検証し, 以下の結論に至った。マン モグラフィで微細石灰化像のみを呈する非触知乳 
癌の診療において,

1) 高分解能超音波装置を用いた乳房超音波検查 は必須である。
2)侵襲の小さいインターベンションによる確定 診断が可能である。

3)縮小手術の適応が可能である。

症例 1 (39歳, 女性)

マンモグラフィ所見：多形性，集簇性の石灰化 (Category III-2)
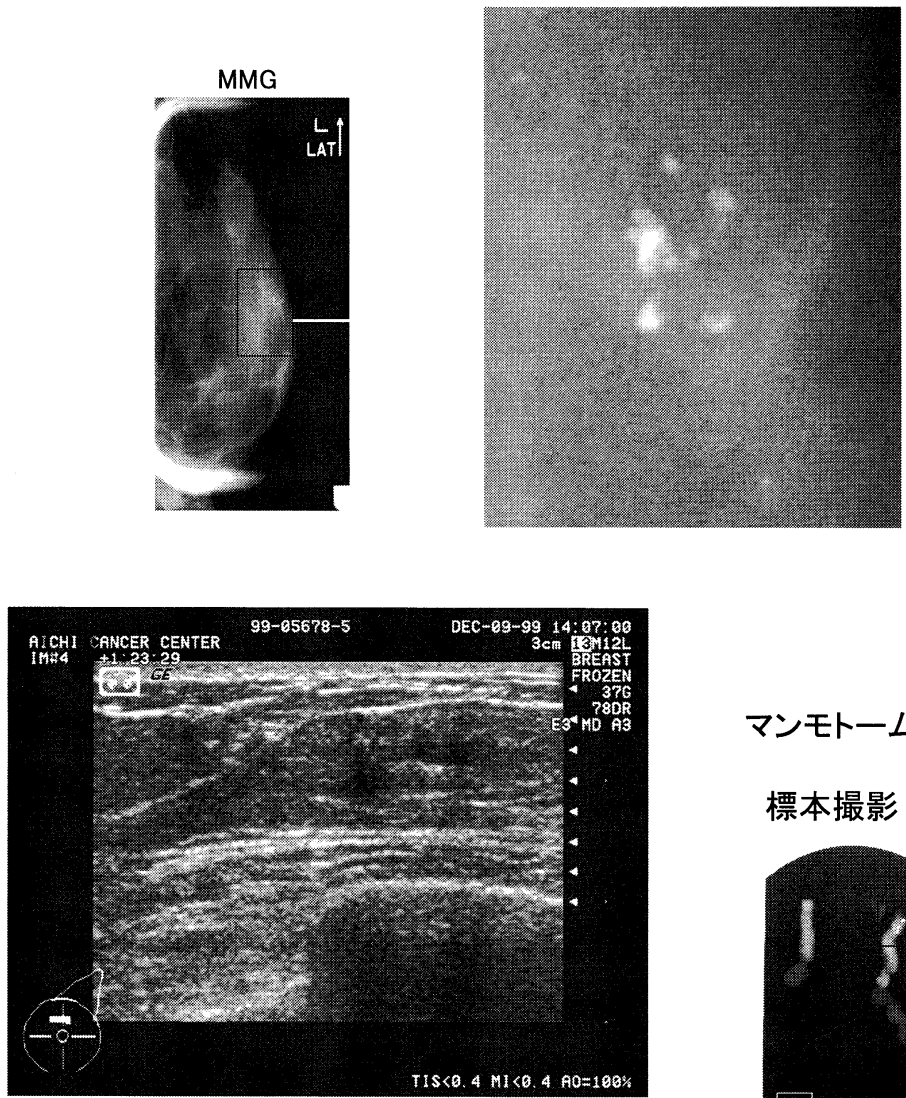

超音波所見：腫瘤像 (-)、echogenic spot(+) USABC : 良性 $\Longrightarrow$ ステレオガイドマンモトーム：FA

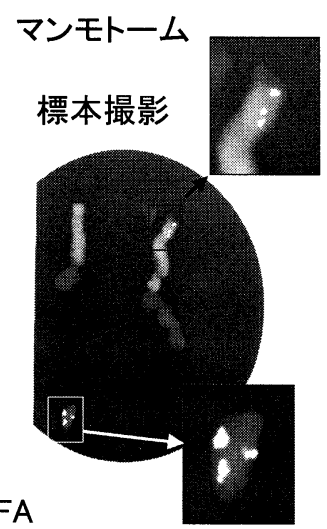


症例 2 (52歳, 女性)

マンモグラフィ所見：多形性，集簇性の石灰化 (Category IV)
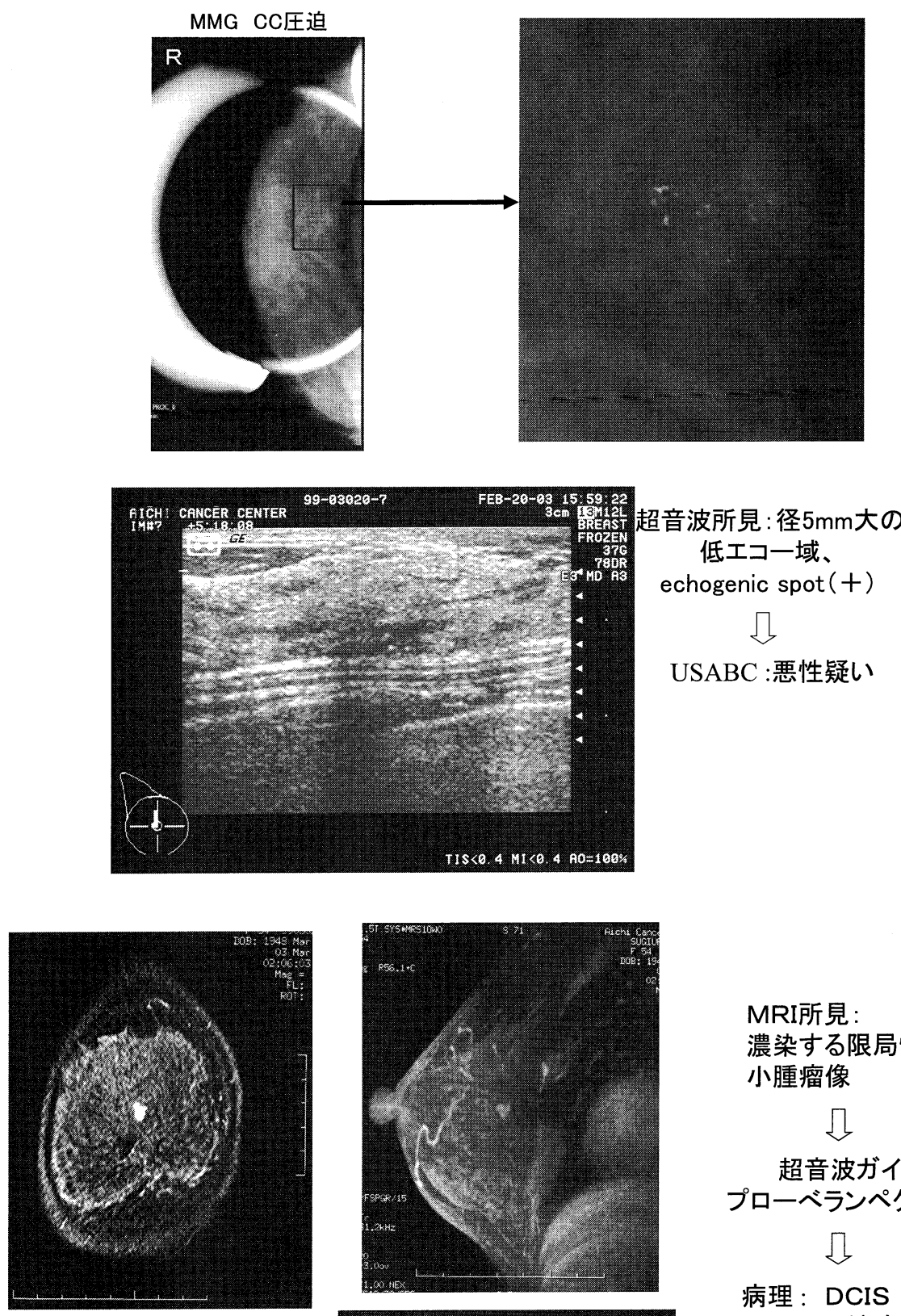
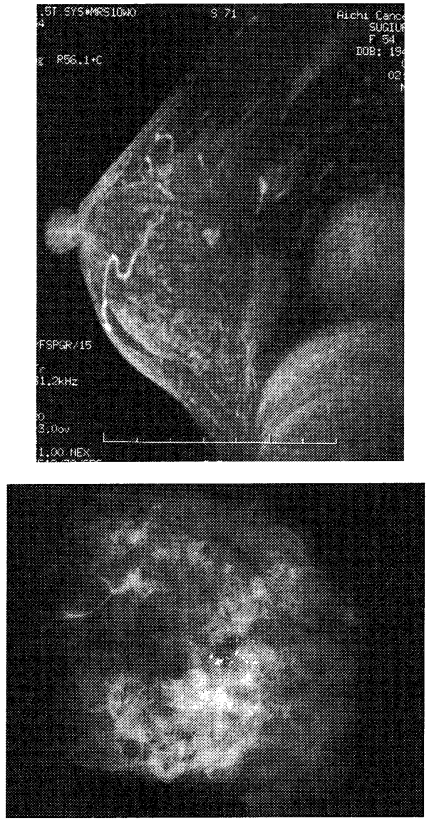

日乳癌検診学会誌(J.Jpn.Assoc.Breast Cancer Screen.) 2004, 13 (2) JUN：173
MRI所見:

濃染する限局性

小腫瘤像

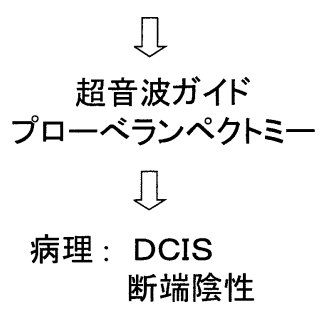

標本撮影 
症例 3 (65歳, 女性)

マンモグラフィ所見：多形性，区域性の石灰化 (Category $\mathrm{V} \sim \mathrm{V}$ )

MMG OBL

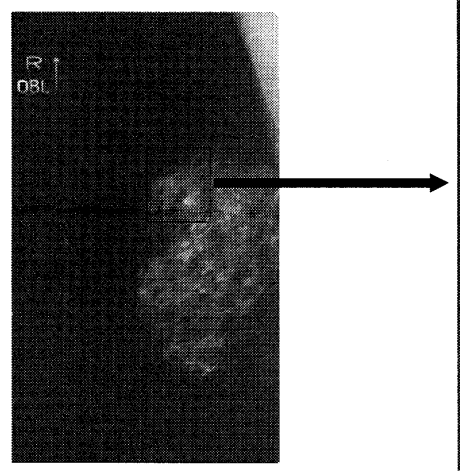

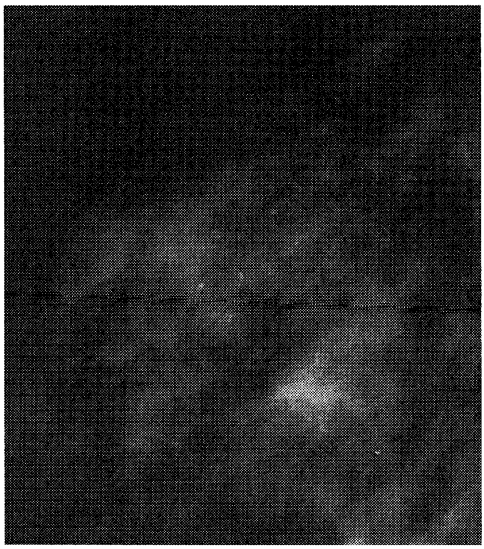

act-3i-63: $\frac{15: 11: 38}{3 c m}$

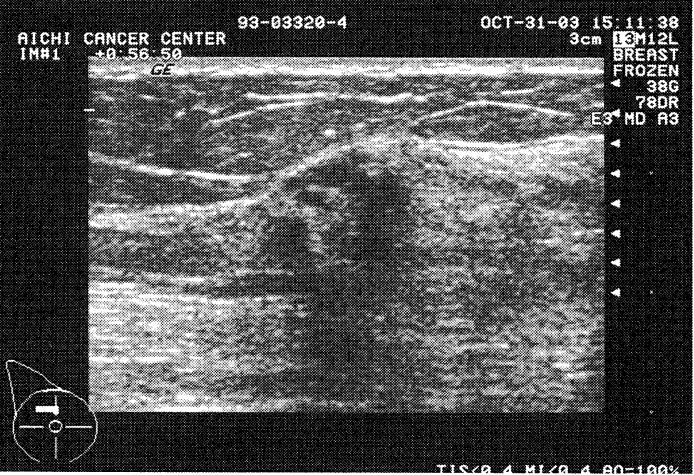

超音波所見: 後方エコ一の減弱を伴う不整形腫瘤、 echogenic spot(+) (CategoryV)

USABC : 悪性 


\title{
A Medical Care System for Mammographically Detected Microcalcifications Associated with Non-palpable Breast Lesions at Aichi Cancer Center
}

\author{
Mitsuhiro Mizutani, Tatsuya Toyama, Keitaro Kamei, Hiroji Iwata \\ Department of Breast Surgery, Aichi Cancer Center
}

Purpose : To evaluate our department's medical care system for mammographically detected microcalcifications (MC) in non-palpable breast lesions at Aichi Cancer Center.

Materials and Methods : Forty-six non-palpable breast cancers with MC seen between April 1999 and September 2002 were included in this study. When high-resolution ultrasound(US) with a highfrequency wideband transducer(GEYMS LOGIQ700MR) showed a lesion corresponding in position to the MC, fine-needle aspiration cytology under sonographic guidance (USABC) was performed. Stereotactically guided vacuum biopsy (SVB) was also used together in some cases. Open biopsy was performed after evaluating the extent of the lesion by MRI in difficult cases. Breast imaging, operative methods, and pathological findings were evaluated.

Results: Of the 46 patients, 37 had US abnormalities. The proportion that presented solid hypoechoic lesions was investigated, and this ratio was judged not to be related to the morphology and distribution of MC, or the presence of cancer infiltration. Among 42 patients, 25 were correctly diagnosed by USABC and 17 by SVB. Among these cancers, 21 were treated by partial mastectomy and 15 by lymphadenectomy.

Conclusions : US is useful for the diagnosis of mammographically detected MC associated with non-palpable breast cancers. With minimal invasiveness, accurate diagnosis of these cancers is possible, and adequate conservative surgery can be devised.

Key words : microcalcification, non-palpable breast lesion, mammography, high-resolution ultrasound, medical care system 